\title{
AUGUSTE DETOEUF, CONSCIENCE OF FRENCH INDUSTRY: 1926-47
}

"A true businessman does not waste time writing reflections about business." 1 Fortunately Auguste Detoeuf disregarded his own selfmocking advice. Throughout his life this thoughtful industrialist articulated the debates and dilemmas of an entire generation of businessmen, especially of other enlightened corporation managers who, like himself, were faced with the problems of industrial modernization and labor relations. The business milieu generally, preoccupied with its own affairs and not inclined to reveal them, provides but few glimpses into the minds and sensibilities which compose it. Detoeuf broke the silence; moreover, his shrewd analyses, unique moral perspective, and wide experience made him a remarkable historical witness to a time of troubles and fundamental change. He provided a rich record of the passage of French employers from the vogue of Americanization in the 1920's, through the crise de conscience provoked by the depression, the Popular Front, and Nazi aggression, up to the new resolve of the Liberation era.

1 Detoeuf, Propos de O. L. Barenton, confiseur, ancien élève de l'Ecole Polytechnique, new ed. (1960), p. 184. A summary of Detoeuf's views in the 1930's is Michel Blain, "Un Aspect des idées patronales dans l'entre-deux guerres: A. Detoeuf et les 'Nouveaux Cahiers"' (unpublished mémoire de maîtrise, Université de Paris-X, Nanterre, 1973). General studies of the mentality of French business in the period 1914-50 are: Maurice Lévy-Leboyer, "Le Patronat français a-t-il été malthusien?", in: Le Mouvement Social, No 88 (1974), pp. 3-49; Henry W. Ehrmann, Organized Business in France (Princeton, 1957); Jean Lambert, Le Patron (Tournai, 1969); Henri Hatzfeld, Du Paupérisme à la sécurité sociale (1971); J. Boudet et al., Le Monde des affaires en France de 1830 à nos jours (1952); Richard F. Kuisel, Ernest Mercier: French Technocrat (Berkeley and Los Angeles, 1967); Patrick Fridenson, "L'Idéologie des grands constructeurs dans l'entre-deux-guerres", in: Le Mouvement Social, No 81 (1972), pp. 51-68; Davis S. Landes, "French Business and the Businessman", in: Modern France, ed. by Edward Mead Earle (Princeton, 1951), pp. 334-53; Patrick Punelle, "Etude d'une mentalité patronale: le 'Nord Industriel' de 1930 à 1935", in: Revue du Nord, LI (1969), pp. 641-50. All places of publication, unless otherwise noted, are Paris. 
Born in Lens in 1883, Auguste Detoeuf rose from relatively modest origins to the heights of the grand patronat. From his grandfather, a farmer-merchant, and his father, the manager of a small factory, he acquired a lifelong respect for hard work and simple living. Although his material means were limited, Detoeuf was able to graduate from the Ecole Polytechnique, the elite engineering school. He had dreamed as a boy of becoming a "great philosopher", then a "great scientist"; later the Polytechnique captivated him with its ideals of scientific objectivity, lucid rationalism and public service. ${ }^{1}$ It reinforced the work ethic of Detoeuf's early youth, and at the same time it seemed courageously modern in a stubbornly obscurantist society. It would appear that Detoeuf's earliest uncertainties were resolved and his energies channeled, at least temporarily, by the civil service career for which the Polytechnique had prepared him. ${ }^{2}$

Many years later, after Detoeuf had gone to work for private industry, he rebuked the Polytechnique for stifling the acquisitive instinct and the natural inclination for risk and enterprise - but his rebuke was touched with indulgence. While he was manager of an important and profitable business, Detoeuf's personal style continued to be extremely modest by the standards of his new milieu. The civil servant's ideals of detachment and esprit de corps molded his opinions throughout his life. While he valued the spirit of progress, he insisted that it need not be wed to ruthless individualism; that indeed it could be far more potent if linked with the broad perspectives of whole industries and entire nations. His experience at the Polytechnique and in government service had been the first steps in Detoeuf's social promotion. Later he was to charge with genuine irritation that the school's brand of abstract logic had been poor preparation for the world of industry in which he, like many other successful public officials, were eventually to find themselves. He had had to learn to balance the logic of an intellectual against "good sense", by which he meant the common sense even a competent workman might possess.

Detoeuf was not always consistent, not always able to blend the claims of authority and fraternity, of the world of the mind and the world of things. He was often uncomfortable with his vocation, especially as he grew older. In his mid-fifties he confided to his friend

1 Letter to Simone Weil (1938), in Detoeuf, Pages retrouvées (1956), p. 95. Interviews with Detoeuf's friends, Guillaume de Tarde and Henry Davezac, provided biographical material.

2 Detoeuf's reflections on the Polytechnique appear in Pages retrouvées, pp. 46-58; Propos, pp. 139-40, 193-201, et passim. He describes a personal influence on his career in his study Le Port de Cherbourg: communication faite à l'Académie de marine, le 24 janvier 1947 (n.d.), pp. 31-32. 
Simone Weil that he was ill at ease as a corporation manager. ${ }^{1}$ At that time he seemed to regard himself as an intellectuel manqué. Another friend said that he resembled a romantic violin virtuoso. He dressed oddly, was habitually tardy, and prodigiously distracted, to a point where he could not drive a car. Detoeuf was never politically radical, but he instinctively disapproved of privilege and hereditary status; he had some leftist friends and at times, leftist sympathies. Dismayed by the superficial, vain forms which cling to power, he felt that he was "a little provincial philosopher" at heart. Indeed, in many of his conversations and writings he viewed the world of French industry as if it were his sentimental "province", a small world of pretense and illusion to unmask, of foibles to mock. But he recognized himself in some of his criticisms, and he tempered them with real affection for his colleagues.

In the early years of the century, however, Detoeuf was a young man at the start of a promising career. As a state engineer with the Corps des Ponts et Chaussées he worked on port facilities. During the First World War he served, until seriously wounded, as a naval engineer, then as administrator of transports in Rouen. Whenever he anticipated severe traffic congestion he would request permission to take preventive measures, and each time his supervising ministry would direct him to do nothing, rather than antagonize some local interest. In 1938, with another war threatening, in another crisis of governmental authority, Detoeuf was to bring out the lesson of this experience: "A government which is ceaselessly subject to public opinion does not wish to, cannot act, until the moment of catastrophe [...] if it is lucky. It cannot fulfill one essential function of government: to foresee."2 Still he continued to place his expertise at the service of the state; for four years after the war he supervised the design and construction of modern harbor installations for the damaged port of Strasbourg. Then in 1924, at the age of forty-one, he followed the common practice of successful state engineers by leaving government service for private enterprise.

$\mathrm{He}$ went to work for Thomson-Houston, the nation's largest producer of electrical equipment. As he described it later, he exchanged a higher salary for a humiliating (if healthy) contact with the petty daily concerns of managing a business, rather than working out the niceties of a theory and merely giving orders for its implementation, as he had been accustomed. Nonetheless Thomson-Houston already belonged to the most advanced sector of French industry when Detoeuf arrived. It was not only a manufacturing giant, but also a vast

1 Pages retrouvées, p. 97.

2 Nouveaux Cahiers, No 33 (November 1, 1938), p. 2. 
holding company with interests in streetcars, railroads, and electric power. From its inception it had had close ties with the American General Electric Company and later, extensive contacts with German business, which Detoeuf himself actively furthered. ${ }^{1}$ With its corporate structure, diverse holdings, and international scope, Thomson-Houston shared little with smaller firms (such as the one Detoeuf's father had managed) which served only the domestic market.

In the mid-1920's the "rationalization" movement - championed by American and German industry - swept up the Thomson-Houston company as it did so many other French enterprises. This was the effort to organize work methods scientifically and to concentrate production. Detoeuf had risen rapidly in the managerial ranks. In the fall of 1925, as directeur-général of Thomson-Houston, Detoeuf accompanied a group of French managers from the major electric power and manufacturing companies to America. They were guests of General Electric and toured the country visiting power plants and factories. Detoeuf drew out the lessons of the American industrial achievement in his lecture to the association of metal and engineering industries the following summer. ${ }^{2}$

$\mathrm{He}$ had been impressed with the way American businessmen co-operated with one another to further mutual interests. Firms from both the power and equipment branches of the electrical industry formed combines to promote a market for electricity, whereas "in spite of many efforts nothing similar has up to now been created in France". It was partly a matter of cultural tradition: "The AngloSaxons and the Germanic peoples have preserved more than we [...] the tribal and clan instinct". ${ }^{3}$ Similarly the fraternal and democratic spirit of the American factory caught his attention. According to a General Electric executive the secret of amicable relations between workers and bosses lay less in fringe benefits than in high pay. But Detoeuf observed that the answer went deeper than wage levels, that there was also a cultural homogeneity of employer and employee: they had had similar educations, enjoyed similar recreations such as baseball. "One feels there that all men are truly equivalent", he wrote, "equal citizens, differing only in their (perhaps temporary) functions. In comparison with a democracy like this, France appears decidedly aristocratic." 4

1 He actively participated in the Comité Franco-Allemand d'Information et de Documentation, which tried in the late 1920's to reconcile French and German industrial interests.

2 Observations sur l'Amérique: conférence faite par M. Detoeuf [...] à l'Union des Industries Métallurgiques et Minières, juillet 1926 (Vannes, n.d.).

s Ibid., pp. 17-18.

4 Ibid., p. 33. 
At the time Detoeuf spoke, the post-war inflationary crisis had peaked, the value of the franc seemed on the verge of disappearing, and as a result there was widespread anxiety among the exporters in his audience. The products of American industry, manufactured at low cost, posed a potential threat to French producers, especially when currency stabilization might eliminate the temporary advantage of the undervaluation of the franc. Detoeuf suggested that French producers defend themselves by following their American competitors' lead: paying high wages, so as to sustain a great internal market on which to base industrial expansion. American firms maintained their momentum by an immense research effort, and by advertising; above all, Americans wanted and needed progress. Frenchmen, on the other hand, characteristically preferred individualized to standardized products; and it was doubtful that French workers could easily be persuaded to abandon their traditional fear that employers would not reward them for raising productivity. With the ugliness of American cities fresh in his mind, Detoeuf doubted that he himself or the French "cultivated class" in general would tolerate so many sacrifices to progress. But "in order for France to preserve la vie douce", it must make certain sacrifices to the laws of economic growth, e.g. less individualism; yet with "the restraint which is, and should remain the French rule", it must make "an effort to develop its potential".1

In articulating his perceptions of the American scene, Detoeuf revealed some concerns that were to occupy him for the rest of his life. There was the appeal of industrial progress with its widespread social benefits; the yearning for community and uneasiness with economic liberalism; and the obstacles and losses France faced in the path toward industrialization. In this prosperous post-war period such reservations were muted by the promise of the rationalization movement. At Thomson-Houston it was evident that progress depended on continual adaptation to new materials, products, and production methods. In 1928, under Detoeuf's guidance, the corporation reorganized itself. It ceded most of its manufacturing plant for heavy electrical equipment to a new company, Als-thom, created by a merger with another large manufacturer. ${ }^{2}$ Detoeuf took charge of the new firm, which immediately ranked with the largest in Europe. Detoeuf had effected a major step in rationalization and had joined the ranks of the grand patronat of French industry.

In this same period Detoeuf first joined an organized movement for

Ibid., pp. 36-37.

2 The Société Générale de Constructions Electriques et Mécaniques was the full title of Als-thom. It had been created by a merger with the Société Alsacienne de Constructions Mécaniques. See Boudet, Le Monde des affaires, pp. 152-53. 
industrial reform. In 1926 a friend and fellow manager from the electrical industry, Ernest Mercier, sought the collaboration of Detoeuf and numerous other experts from business, academia, the high civil service, and the military in formulating comprehensive proposals for the renewal of economic, social, and political institutions. The American model, a responsible business elite, and a pragmatic reforming temper were the heart of Mercier's inspiration. His organization, the Redressement Français, became the prime mover for technocratic reform among French businessmen. ${ }^{1}$

Detoeuf wrote the movement's key report on industrial reorganization in $1927 . .^{2}$ In it he addressed himself to the plight of manufacturers, greatly threatened (as he had noted the year before) by competition from America, Britain, and especially Germany. The dispersion and fragmentation of French industry discouraged investment, kept prices high, and bred ignorance of foreign markets. The establishment of cartels, on the German model, would allow an industry to survive a battle with its foreign competitors; but concentration of production was a far superior solution for France. Concentration would correct fundamental irrationalities with economies of scale, the capacity for research and development, and the mechanization of work. ${ }^{3}$ The state had little role in Detoeuf's scheme. He asked primarily that the government reverse its harmful policies and attitudes - the protection of situations acquises, the greater esteem accorded to agriculture, the treatment of industrialists as "a crowd of unscrupulous types from whom one must always be wresting their more or less illgotten gains". 4 At most, the state should remove these impediments to rationalization and ensure fair treatment abroad for French exports. In later years Detoeuf grudgingly accepted a certain amount of government intervention in the economy, justified only by an acute crisis, and as a hedge against more complete state control. But first as a professional engineer, then as a businessman, he had not been impressed with politicians; nor was he impressed by the practical wisdom and ethical implications of either leftist or rightist economic programs as these were proposed in the course of his career. On this point he kept fairly close to the liberal tradition.

Detoeuf's project rested ultimately on the industrialists themselves

1 Kuisel, Mercier, pp. 45-88.

2 La Réorganisation industrielle [Les Cahiers du Redressement français, No 7].

${ }^{3}$ Detoeuf denied that concentration would harm the rural artisan. He predicted, to the contrary, that mechanical power supplied by rural electrification added to the French artisan's "unequaled flexibility" and ability to "make-do" (débrouillage) would promote an "artisanal renaissance". Only medium-sized firms, he argued, would disappear (ibid., p. 32).

4 Ibid., p. 55. 
and on such collective psychological and moral imponderables as the "will to progress" and the "sense of solidarity". 1 French industry was threatened not only externally, by foreign competition, but also internally, by its own neglect of social evolution. Prudence, parsimony, and the taste for the unique, which had made France's fortune earlier, had become liabilities. It showed "lack of solidarity" when the employer held down workers' wages and found an inadequate market, when a worker limited output and accordingly prevented wage increases, or when a client demanded a special product when the standard model would suffice. "The divergence of wills, absolute freedom - this ideal of the liberal school - involves a considerable loss of vitality", he wrote. ${ }^{2}$ The scientific organization of work ("Taylorism") must be accompanied by confidence that profit would come from increasing the volume of sales although the profit margin per unit declined.

A greater internal market sustained by advertising, product standardization, the extension of credit, and especially, high wages Detoeuf seemed to have fewer doubts than ever that the American model might well be imitated in France. He had also formulated more clearly his ideas on how the new solidarity could be brought about, utilizing existing French institutions. Schools might instill the appropriate ideals in students. Employers' associations could influence their members' behavior instead of merely defending business against the state and trade unions. Detoeuf advocated that they be transformed into centers of positive action, and he took this proposal as a personal mandate. He joined, and later presided over, the Commission Générale d'Organisation Scientifique (CEGOS). This organization, affiliated with the employers' federation, the Confédération Générale de la Production Française (CGPF), attempted with little success to popularize the rationalization movement. ${ }^{3}$ A more substantial effort was Detoeuf's renovation of his own trade association, the Syndicat Général de la Construction Electrique (SGCE). The association had floundered through indifference until Detoeuf led Als-thom, the industry's principal enterprise, into it. ${ }^{4}$ Detoeuf assumed control and astonished his colleagues by subordinating Als-thom's interests to the welfare of the industry, and by creating a spirit of mutual trust. The SGCE quickly became a model for the entire employers' movement.

1 Ibid., pp. 34-44.

2 Ibid., p. 1.

3 For Detoeuf and CEGOS see: Detoeuf and Rolf Nordling, La Comparaison des prix de revient, facteur de progrès? (1956); Detoeuf et al., Les Techniques statistiques appliquées à la direction des entreprises et des groupements professionnels (1942); Bulletin bi-mensuel de la CGPF.

4 Revue générale de l'électricité, LVI (1947), 32-33B. 
Of all types of manufacturers, the electrical construction industry was the most severely struck by the great depression. One authority estimated a fifty percent drop in sales since the arrival of the crisis. ${ }^{1}$ In 1933 the prestigious Ecole Libre des Sciences Politiques invited Detoeuf and other prominent experts to a conference on the depression and international trade. Detoeuf's speech marked the emergence of a new outlook: a retreat from economic liberalism, waning enthusiasm for rationalization, an intensified search for community. ${ }^{2}$ He declared that one tenet of economic liberalism, that of free trade, had already been eclipsed by the states which closed their commercial frontiers, and by firms which engaged in the dangerous practice of "dumping". On the other hand, agreements among large competitors to share markets, such as the one recently negotiated between French and German electrical manufacturers, was a necessary and desirable solution even if they violated another hallowed rule of liberalism. For one could not stand by while misery and destruction spread and wait for economic laws to correct the crisis. Turning from his previous technocratic views, he now accepted "a pause" in economic growth. He further suggested that France's economic position was relatively healthy because it had been "more steady, less hasty and frenetic in the development of material well-being" than in other countries. ${ }^{3}$ A further limit on expansion through the use of cartels and import quotas would be acceptable if (as he expressed it) France caught its breath and thereby avoided a heart attack. Als-thom itself entered a cartel and cut its operations drastically.

As political turmoil followed the economic crisis, Detoeuf was drawn to consider problems broader in scope than those presented by his own industry. On February 6, 1934, political violence erupted in Paris as right-wing demonstrators tried to storm a session of parliament. To some it seemed that the Third Republic had narrowly escaped a fascist seizure of power. Soon afterwards, at one of his favorite cafés, Detoeuf began meeting with several friends to discuss the situation. These casual luncheons were to generate one of the most significant developments among employers in the 1930's, the founding of the Nouveaux Cahiers circle. (Their deliberations, however, did not appear in print until 1937.) Detoeuf himself was developing a more extensive critique of liberal doctrine than he had previously attempted.

In the spring of 1936, during the elections that brought a leftwing coalition called the Popular Front to power, Detoeuf delivered a

1 Ibid., XXXVIII (1935), 82U.

${ }^{2}$ Conférences organisées par la Sté. des Anciens Elèves et Elèves de l'Ecole Libre des Sciences Politiques [La Coopération Internationale] (1933), pp. 3-57.

${ }^{3}$ Ibid., p. 43. 
lecture in which he declared that economic liberalism was not absolute truth, but a historical doctrine no longer adapted to modern circumstances. "Liberalism is dead", he announced to a distinguished audience of progressive engineers and employers; "it was killed not by human design or by wilfull governments, but through an irresistible internal evolution." This evolution had exacted a positive response from governments everywhere. The masses, Detoeuf believed, were not revolutionary in temper, but they did demand state intervention on behalf of those harmed by the depression, a modest redistribution of wealth, and enlarged public services. He had once had faith in the operation of the classical economic laws, he confided; yet he could not rationally continue to advocate a process of change whose price was thirty million men out of work each decade. We must recognize, he said, that the classical laws were modeled on the economic conditions of the eighteenth and nineteenth centuries. These laws continue to operate tolerably well in the older sectors - among artisans, professionals, and small businesses - where similar conditions still prevail. But, Detoeuf discerned, it was in the modern, corporate sector where actual practice had come to diverge widely from liberal principle.

"The new element which has intervened in the modern economy born of liberalism, is productive capacity - this abstract being which, once created, refuses to die."2 Liberal theory held that a firm would necessarily shut down when profit margins narrowed; but under modern conditions it continued operations, accepting lower prices and waiting for an improvement in the market, or even sold abroad at prices below cost in order to recover part of its expenses and build future clientele. As a corporate executive himself, Detoeuf knew that a salaried professional manager, unlike the owner of the liberal model, was less willing to liquidate since the capital belonged to others; he had no investment to save, and liquidation would serve to condemn his management. Creditors too, rather than sacrifice the bulk of their investment, extended further support and the firm lingered for years. And international competition no longer eliminated the inefficient producer: it provoked struggles between national industries where bankers, suppliers, and even governments aided the endangered firm. Finally, Detoeuf pointed out, the public no longer behaved like

1 They were members of X-Crise, a study group devoted to finding new ways to combat the depression. Most were graduates of the Polytechnique. See Guy Desaunay, "X-Crise, Contribution à l'étude des idéologies économiques d'un groupe de polytechniciens durant la grande crise économique, 1931-1939" (unpublished thesis, Université de Paris, 1965). Detoeuf's lecture is "La Fin du libéralisme", in: Bulletin du Centre Polytechnique d'Etudes Economiques, Nos 31-32 (1936), pp. 37-51. The quotation is on p. 37.

"La Fin du libéralisme", pp. 43-44. 
the homo economicus of classical theory. Now the mass of consumers and stockholders, armed with credit and market information, anticipated and intensified fluctuations rather than regulating them. Hence the price mechanism, instead of moderating the business cycle, now aggravated it.

In Detoeuf's analysis, then, not the capitalists but rather an impersonal development involving all members of society was responsible for the depression. Detoeuf dimly recognized the issues which were to bring about the victory of the Popular Front, however, by acknowledging that liberalism had sanctified egoism and had undermined "civic morality" in the business community. Businessmen would have to demonstrate that they could act in the public interest if they wished to resist the drift towards state control. They would have to renounce their right to harm their fellow men, to speculate, and to act in secret in order to retain their basic liberties. Only a consciousness of rational self-interest, based on the economic interdependence of all members of society, would serve to protect freedom. Like many other observers of the 1930's, Detoeuf believed that the French had lost the sense of community. But he believed that it could be regained, for it was as deeply rooted in human nature as selfishness, although it was buried below the surface of man's daily experience.

Detoeuf realized that once brought into public consciousness, the interests of the whole community would still have to be interpreted and defended. But here his reasoning foundered: a conception of the new society does not emerge clearly from his sketch. First he proposed a "quiet revolution" from above, which would entail the suppression of "classes based on hereditary wealth and social connections" and the voluntary creation of "production groups". These new economic institutions would remain independent of one another and of the state, yet they would operate in the open and with sufficient mutual confidence as to reduce to a minimum the need for outside mediation and control. Clearly the production groups were to be the principal defenders of community interests: "We [the managers and employers] will be true leaders, that is to say, true servants." If the business elite should fail to take up its appointed task, he warned sharply, "we shall go from statism without conscience to anarchy without scruple"; at best, mere youth, vitality, and a generous spirit would prevail against wiser heads if the latter proved too sluggish in bringing reform. ${ }^{1}$

This last prognosis, presented by Detoeuf as the dramatic finish to his lecture, demonstrates that he was at least aware of the restlessness of popular leaders; but as he later confessed, he had very much

1 Quotations in this paragraph from ibid., pp. 50-51. 
underestimated the intensity of dissatisfaction among the rank and file of the working class. His plan had not offered much to labor; what little there was came down to a more respectful manner towards the working man, but no sharing of decisions. He had sincerely believed that critics of business would be satisfied by the restitution of responsible authority. Hence like so many other employers, Detoeuf was surprised and distressed by the massive sitdown strikes of May-June 1936, the most disruptive the Third Republic had seen. The Als-thom plants were among those occupied. To many these occupations foreshadowed a seizure of industry by the workers, possibly acting under Communist direction.

Some months before Detoeuf had arranged employment in one of his plants for Simone Weil, then a young agrégée in philosophy, who had wanted to experience directly the life of an unskilled laborer. At the height of the strikes Weil wrote to her employer in an effort to explain that the source of trouble was the degrading character of factory work, so perfectly symbolized by the eating-machine in Chaplin's film Modern Times. ${ }^{1}$ Despite your good intentions, she told Detoeuf, you have done nothing to relieve the laborer's feelings of utter hopelessness. For her part Weil applauded with unmixed enthusiasm the self-assertion of her comrades. Detoeuf explained that he was powerless to do much himself - yet the young intellectual's criticism evidently put him on the defensive. He told her he believed that personal dignity was a characteristic of the inner life which did not depend on external circumstances; then (in a still more lofty tone) he added: "Nothing is important except what I might have done for eternity, and have not done." 2 Detoeuf meant that he might have become an intellectual who dealt in eternal verities; instead he was condemned to the world of action. That world, when dominated by "mass passions" in which reason and the individual had little weight, he found both unworthy and intimidating.

However, Detoeuf was soon to discover his true métier. From early 1936 ranking civil servants, academics, bankers, writers, and nonCommunist labor leaders, among others, joined the circle of industrialists who had begun weekly discussions in the wake of the 1934 political crisis. ${ }^{3}$ These men shared only "the same desire for a peaceful

1 Letter in Simone Weil, La Condition ouvrière (1951), pp. 181-84.

${ }^{2}$ Letter in Pages retrouvées, p. 96.

3 The founders of this group in 1934 besides Detoeuf were: Jacques Barnaud (directeur-général of Worms et Cie.); Henry Davezac (an official of the SGCE); M. Isambert (industrialist); and Guillaume de Tarde (director of the Cie. des Chemins de Fer de l'Est). The sources for the group's founding are: interviews 
renewal, the same effort to understand one another, the same repugnance for set opinions". ${ }^{1}$ Their common opposition to communism was a less explicit theme: they sought "positive solutions" "apart from passion, especially mass passions".2 In 1937 their debates and proposals began to appear in a new review, the Nouveaux Cahiers, which soon became the most prominent forum for enlightened public discussion among employers. Subcommittees composed of spokesmen for opposing interests formulated specific recommendations to meet problems like workers' housing, the recruitment of civil servants, and constitutional reform. The Nouveaux Cahiers group displayed technocratic convictions. Its appeal was to elite individuals of bonne volonté to rise above party and class in search of rational, constructive solutions. The young Albert Camus praised the review for its impartiality and realism. ${ }^{3}$ As the inspiration of and major contributor to the review, Detoeuf shed the weariness and sense of alienation induced in him by the strikes. His reputation among employers grew rapidly.

In the course of 1937 Detoeuf wrote a series of sympathetic yet critical articles on the Popular Front and its head, the Socialist Léon Blum. ${ }^{4}$ He thought that it was in the interests of investors and businessmen to maintain their loyalty to the government so as to prevent its falling into Communist hands. On balance Blum's economic policies had not hurt the export position of machine manufacturers, he reported. Yet he warned Blum not to permit continuing labor unrest that would disrupt the whole economy - for there could be no production without discipline and no justice without authority. Detoeuf later explained the fall of Blum's government (in June 1937) as a failure to enforce its own laws; it had been a prisoner of its socialist mystique, working-class constituency, and political allies. But Detoeuf did not miss the ethical appeal of Blum's character, in which he saw something of himself: he speculated that Blum was too attached to freedom and equality to employ any means of governing other than negotiation and persuasion. Perhaps he had lacked confidence or had underestimated his own political strength. In the end Detoeuf hoped that the Socialists had learned from their errors and that once

with Henry Davezac and Guillaume de Tarde; Nouveaux Cahiers, No 1 (March 15, 1937), pp. 2-4; No 6 (June 1, 1937), p. 2; No 11 (October 1, 1937), pp. 2-6; No 20 (March 1, 1938), pp. 13-18. Hereafter the Nouveaux Cahiers will be cited as $\mathrm{NC}$.

1 NC, No 1, p. 2.

2 NC, No 20, pp. 15-16.

3 Roy Pierce, Contemporary French Political Thought (New York, 1966), pp. 128-29.

4 NC, No 1, pp. 4-6; No 3 (April 15, 1937), pp. 2-5; No 4 (May 1, 1937), pp. 2-5; No 8 (July 1,1937 ), pp. 2-5. 
the economy revived "a democratic experiment can and must succeed". 1

The Popular Front coalition lingered on despite Blum's withdrawal, and industrial unrest continued into late 1937. Labor and management exchanged accusations of sabotage. In the Nouveaux Cahiers Detoeuf denied that either side was intentionally obstructing production. ${ }^{2}$ $\mathrm{He}$ calculated that if one took into account the current disorder, output per worker had not actually diminished. As for the employer, he would have had to be "a saint or a hero" to have accepted the Popular Front's legislation without a certain amount of "bad grace"yet even he was unlikely to turn down a remunerative order and give his competitors an advantage simply to spite his workers or the government. The production lag was due rather to technical difficulties like irregular deliveries, shortages of skilled labor and capital, conflicts over contracts. Simone Weil disagreed with Detoeuf. She thought that employers were much more hostile than he had estimated, and in support of her contention she cited a bitter conversation she had overheard on a train between two prosperous-looking employers. Complaining that their freedom to hire and fire had been violated, they had talked of "losing everything", of going on strike themselves in what they called "the employers' Battle of the Marne". 3 In reply Detoeuf observed that the travellers had probably exaggerated their sentiments so as to give the impression that they "possess more energy and solidarity than is in fact the case", but their distress was real. They risked their fortune in their firms, asked for no help and expected none, learned to suspect competitors, suppliers, buyers and employees, ruined rivals without remorse because everyone else did the same thing, believed their duty to society was to make money, and that under the existing regime only threats and violence were effective. "And you", he told Simone Weil, "expect that they alone should go on trying not to embarrass the government, a government supported by a party which aims at totally dispossessing them!"4

The experience of the Popular Front had drawn attention to the question of the proper relationship between interest groups and politics. Detoeuf's response was delivered as a lecture in early 1938 and later published under the title Construction $d u$ syndicalisme. It became one of his best-known works. In reconsidering the events of 1936, Detoeuf was more than ever convinced that the political arena was not the best place to settle economic and social questions. Even the beneficial reforms of the Popular Front had been "more abrupt"

1 Quotes in this paragraph from NC, No 8, pp. 4-5.

2 No 13 (November 1, 1937), pp. 9-13.

3 Letter to Detoeuf, in Weil, La Condition ouvrière, pp. 188-90.

4 Letter to Weil, in NC, No 16 (December 15, 1937), p. 6. 
and "less durable" than labor wished. Yet the "explosion" of 1936 had largely resulted from the employers' failure to recognize the workers' needs - Detoeuf confessed that he too had not fully comprehended the material and spiritual distress of factory hands - and once recognized - to respond generously. Employers were naturally suspicious of the labor unions, which interfered with their control and seemed increasingly identified with the Communists. Detoeuf contended that a realistic program to bring the two sides together for negotiation must not only defend the workers' interests but must also recognize the contribution of employers in the production of wealth. It must support the values on which their contribution rested - individual effort and initiative, foresight and respect for contracts; it should in general maintain the division of labor and the hierarchy of responsibility.

As Detoeuf thought through his program he arrived at the formula he had searched for since the onset of the depression, the middle way between Marxism and liberalism: it was "double syndicalism". By this term he meant the parallel organization of employers and workers; both employers' associations and trade unions were to be "compulsory, unique, and apolitical". He knew that employers had always preferred self-reliance and had been mistrustful of associations with one another; yet the depression and June 1936 had partly overcome their traditional resistance. If it were obligatory, an employers' association would not only present labor with a bargaining partner, but it would enable an industry to act together in meeting common problems such as ruinous competition, wage levels, working conditions or inadequate statistics. There were inherent advantages in having such issues treated uniformly by competing firms. Detoeuf thought that there would be chaos in the plant if factory committees negotiated directly with management, as in the Soviet Union; the employers' association, on the other hand, would preserve managerial authority.

Later, in the course of defending his plan against the counterproposals of a corporativist critic, ${ }^{1}$ Detoeuf reaffirmed his faith that mutual respect and the satisfaction of basic needs would be sufficient to maintain social order - that too much explicit insistence upon the spirit of hierarchy and authority would alienate the workers. $\mathrm{He}$ directed employers not to distort his scheme by erecting their own company unions; rather they should rely on tough arbitration laws to make strikes and lockouts exceptional. In short, he was far from wishing to create a mere façade for the domination of employers; but he hoped that their needed co-operation could be gained by a program which promised peaceful labor relations. Moreover, speaking

1 See below, pp. 164f. For corporativist doctrine see p. 171 and note 2 . 
from the employers' perspective, Detoeuf warned gravely that unless the existing economic disorder gave way to systematic collective bargaining, unless an improvement in the lot of the masses resulted, one might expect a revolution leading to a leftist tyranny or to the imposition of a fascist order from abroad.

Detoeuf insisted that his scheme was pragmatic and apolitical. ${ }^{1}$ In abandoning his earlier project to restructure the economy on the basis of "production groups", he had come to accept more readily social forces as they were currently organized. His "double syndicalism" would reinforce both sides of the labor question; the fact that each would be invested with appropriate powers recognized by the other could assure a certain reduction of friction. Furthermore he attempted to demonstrate that the character of negotiations would be intrinsically altered under a regime of "double syndicalism". He drew first a rather dubious distinction between "politics", which was so much endless wrangling, and the negotiation of "interests", which could end in a judgment or a compromise. Detoeuf imagined that the demands arising from the needs of separate interests would be muted; while scientifically-conceived issues would be the substance for negotiations. Politics were marked, he noted, by "ruse, trickery, rhetoric and demagoguery" - while the ethics natural to a purified, technocratic, problem-centered forum were those of "mutual assistance, the morality of collective interests surpassing the group and seeking the good of each in the good of all".2

It was generally his attempt to separate the economic from the political life of the nation, rather than the details of his proposal for structural reform, which drew the attention of Detoeuf's critics. Construction $d u$ syndicalisme stimulated a lively public debate with representatives of labor. The sympathetic union official Georges Lefranc applauded Detoeuf's recognition of the material deprivation of the working class, yet insisted that the millenarian hopes and the political vision of a new syndicalist society were intrinsic to the labor movement. ${ }^{3}$ Other representatives of the Confédération Générale $d u$ Travail (CGT) also objected to Detoeuf's proposal to deprive the trade unions of their right to political protest, especially when democracy was in danger, and they claimed that a unified employers' movement

1 Detoeuf recognized that employers, like workers, could not ignore politics altogether, but he thought that they could and should conduct their political activities as private citizens rather than as members of a union. Thus employers' associations should not subsidize political parties as they had in the past nor should trade unions interrupt work for political demonstrations. Construction du syndicalisme (1938), pp. 48-50.

2 Ibid., pp. 59, 62.

${ }^{3}$ La Tribune des fonctionnaires, October 15, 1938. 
would intimidate labor. ${ }^{1}$ Detoeuf's rebuttal contended that, on the contrary, it was the weakness of employers' associations that prevented them from helping workers by regulating production and thereby better assuring employment. To the Marxist argument that the class struggle arose out of economic conditions and was not merely the result of misunderstanding, Detoeuf provided the technocratic response: his program would change those conditions.

Simone Weil, too, took up labor's challenge to Detoeuf, connecting it in Sorelian terms to her experience with the working class. She accused her former employer of reducing the trade-union movement to the status of a mere interest group. But syndicalism had psychological and moral as well as economic dimensions: it grew out of the degradation of labor. In order to endure humiliation and to resist the power of the bosses, Weil argued, the worker needed a revolutionary ideal that held the promise of reversing the existing social order. Compulsory unions would destroy the spiritual value and energy of syndicalism: "Syndicalism is neither an association of interests, nor the application of a doctrine: it is a profoundly popular movement which demands free adherence. Its origin is as dark as that of the Greek tragedy or the folksong; it represents a surging force with its own heroes, martyrs, and saints." She warned Detoeuf that his program of social peace would bureaucratize unions, create a passive working class, and perpetuate inequality: "Savage, anarchic, illegal demonstrations would alone represent what is most noble and most legitimate in the workers' movement." 2 Detoeuf again gave the technocrat's rejoinder: "The class struggle symbolizes a tension which leads to [...] tyranny. If we desire the progress of humanity, we must base [our program] not on the class struggle, but on human betterment."3 He continued to keep faith with the moral intent of this formula, however tautological; but later he tried to meet the accumulated opposition from labor by introducing voluntary membership and more diversity among unions into his plan.

Most of Detoeuf's fellow employers withheld their reaction to "double syndicalism". But one of them attacked him for proposing a "timid and incomplete" scheme which tried to wish away politics and would only serve to heighten the class struggle by organizing business and labor for combat. ${ }^{4}$ This theorist preferred to see the warring CGT and CGPF replaced with an "assembly" for each "pro-

1 NC, No 24 (May 1, 1938), pp. 5-6.

2 Ibid., pp. 2-3.

3 Ibid., p. 5.

4 NC, No 39 (February 15, 1939), pp. 13-18. Detoeuf's response also appears here. 
fesssion". These assemblies would be armed with legal powers and wide social and economic responsibilities; composed of both workers and employers, they would become the basic units of a national, hierarchical, corporativist system. He thought that the workers were "perverted" by Marxism, but they would be reformed under his system by "the law of work and the respect for family and hierarchy". Detoeuf and his critic agreed that the doctrine of class struggle was not applicable to industrial relations. But Detoeuf openly recognized the differences between workers and employers (he considered them interest groups with varying occupations and incomes rather than classes which denoted cultural and political disparities), and he was doubtful that the harmonizing potential of the "profession" could obliterate these differences. On the other hand he was willing to entrust their settlement to collective bargaining. Detoeuf realized that the two proposals differed more in spirit than in form - but the spirit was crucial. Rejecting the other employer's harshness and authoritarianism, he preferred rational negotiation and mutual respect.

Detoeuf's reputation was at its peak when Propos de O.L. Barenton, confiseur was published in 1937. The fictitious narrator and protagonist, Monsieur Barenton, is introduced with a sympathetic if slightly mocking sketch. Barenton is the archetype of the Americanized entrepreneur. A visit to the United States has transformed his aspirations: on his return he proceeds to build an international icecream empire based on advertising, a network of subsidiaries, and standardized products. Barenton succeeds not only because he uses modern techniques, but because he is sensible, independent, and perceptive. $\mathrm{He}$ is, of course, Detoeuf himself in many ways, and his "sayings" express in witty form Detoeuf's own wisdom and insight into the world of French business. On one level the Propos are a kind of parlor game, a self-conscious attempt to produce bons mots in the urbane tradition of French moralists from La Rochefoucauld forward. The inherent silliness of Barenton's product, ephemeral ice cream, is a clue to the book's manneristic irony. At times, the scepticism is lighthearted; at other times it becomes downright gloomy and pessimistic. For on another level, the book is a serious review of the aspirations and experiments of the previous two decades, revealing in particular the stormy encounter of old and new methods, traditional and modern social types. This was the eve of the Second World War, when Detoeuf wrote rather bitterly, "The French industrialist lives in the present, with the past. He asks nothing of the future."1

1 Propos, p. 68. There is an illuminating comparative sketch of a typical German, British, French and American industrialist of the 1930's (pp. 62-69). Of the more entertaining maxims is: "There are three ways to ruin oneself according 
But Detoeuf had not abandoned the employers' movement. He was carried into a leading position in the Comite Central de l'Organisation Professionnelle (CCOP), an affiliate of the CGPF.' The typical member was a middling employer from the metallurgical industry. Its purpose was to propagate corporativist solutions to current social and economic problems. In 1938-39 Detoeuf directed several educational programs, the most important of which was a study group of young employers within the CCOP; this organization was to grow into the influential Centre des Jeunes Patrons of the post-1945 period. In a speech before an enthusiastic assembly of the young employers Detoeuf criticized the paternalistic conception of the ideal employer. ${ }^{2}$ The new patron social would be less a teacher or father in relation to his employees than a leader. His authority would come from their respect for his competence, dedication and fairness, not from the awe which wealth and seclusion can inspire. Traditional paternalistic services like company housing should be initiated by the workers' demand for them and then administered by the employers' associations. The patron should not interfere with the functioning of any peaceful union (even Communist), but should attend to the sound operation of the entreprise.

Nouveaux Cahiers, too, tried to fuel the rising concern with industrial reforms. In June 1938, the review sponsored a workshop held at the Abbey of Pontigny, where progressive industrialists and trade union officials met with their Swedish counterparts to examine industrial relations in Sweden. ${ }^{3}$ The Swedes stressed the organization of labor and management, their mutual respect, and their reliance on collective bargaining and social assistance programs. In spite of serious conflicts, the dialogue within Swedish industry seemed informed by "good sense", and it was free of the rhetoric which concealed the real economic issues in France. Once more Detoeuf concluded that because of the weakness of French syndicalist structures, union leaders could not control workers without demagoguery; the owners used deception because they felt isolated and insecure. Mutual trust could only be built on a foundation of solid syndicalism. Returning to the theme of the "new employer", Detoeuf stressed the need to treat the

to the great Rothschild: gambling, women, and engineers. The first two are more pleasant, but the latter is more certain" (pp. 124-125).

1 Statuts du Comité Central de l'Organisation Professionnelle (1939); "Compte rendu de l'Assemblée générale du Comité Central de l'Organisation Professionnelle, 18 janvier 1939", in: Bulletin bi-mensuel du CCOP, No 53 (February 25, 1939).

2 NC, No 26 (June 1, 1938), pp. 1-4.

3 For Pontigny see Detoeuf's preface to Paul Planus, Patrons et ouvriers en Suède (1938), and NC, No 29 (July 15, 1938), pp. 2-4. 
workers as equals whose subordination was limited to the work day, and the desirability of supporting social reforms which "tend [to produce] the assimilation and fusion of the classes". ${ }^{1}$ But the Pontigny meetings served as a pretext for a fresh division of the labor movement itself. According to one account, they were "saluted by some as the dawn of a new social experiment in France, and decried by others as a despicable betrayal of syndicalist principles". ${ }^{2}$ A leftist spokesman declared that the Swedish model was irrelevant because the recent experience with collective bargaining in France proved that employers could or would not negotiate in good faith. ${ }^{3}$ Some labor leaders who had been present at Pontigny later denied that they had come as representatives of their unions. ${ }^{4}$ Even the representatives of the union of civil servants, who praised Detoeuf's conception of "the employer's social role", also criticized him for insisting on "a leader who commands and the masses who carry out [orders]". 5

Detoeuf's attention was already divided between his efforts to feel his way among the clashing opinions on domestic questions, and his attempt to comprehend the steadily more perplexing international crisis. In a general sense his hatred of war and tyranny, both fascist and communist, informed his views. He had made a visit to the Soviet Union in October 1935, as part of an effort to add commercial ties to the incipient Franco-Soviet diplomatic rapprochement. The oppressive Stalinist regime shocked him: it was based, he thought, less on economic materialism than on enthusiasm and fear. The Leninist dream of a classless society had faded before new forms of social stratification and the power of a party elite. His repugnance for the Soviet regime was nourished, of course, by the fact that the Communist party was the principal obstruction on the Left to his plans for class conciliation at home.

But more precisely, Detoeuf's view of France's place in world affairs depended on his assessment of the character and potential of her economy. In an article on commercial policy that appeared in 1937, he expressed his doubts that France could or should become "a great industrial nation": given the small size of its internal market, its prudent bankers, its low birth rate, its indecisive Republic, France was not an "invader" country, economically or militarily. French

1 Planus, Patrons, p. 15.

2 Henry W. Ehrmann, French Labor from Popular Front to Liberation (New York, 1947), p. 201.

${ }^{3}$ La Révolution prolétarienne, July 25, 1938.

4 Le Temps, June 27, 1938.

${ }^{5} \mathrm{La}$ Tribune des fonctionnaires, June 11, 1938. 
producers could not hope to compete with the foreign industrial giants. In a striking passage the man who would call himself "a little country philosopher" attributed the genius of his compatriots to their background as small farmers. French resourcefulness, ingenuity, and taste - the lifeblood of the luxury métier - derived from a long history of loving cultivation of small parcels of land. French moderation and cautiousness stemmed from long struggle with nature's capriciousness. Yet these talents for "taste and good sense are the noble aspects of a contented mediocrity". 1 The gloom of the 1930's seemed to have overwhelmed Detoeuf's Saint-Simonian aspirations of the 1920's. The playful tone, which barely covered Detoeuf's anxieties for the future in the Propos, had become wistfully ironic.

France was clearly threatened and Detoeuf began to consider that the economic parity he had fought for was perhaps too distant to serve as a defense - perhaps, too, its cost would be excessive. It would be necessary to change the spirit of banking, industry, and politics, abandon protection of the small farm, scorn small commerce and industry, respect the strongest and the biggest, and become a nation of speculators, entrepreneurs and conquerors. "France would cease to be a land of small folk, orators, rentiers, artisans, idlers and sceptics, a land of equilibrium and easy pleasures".2 Detoeuf felt that it might be best if France limited her economic goals and relied upon the development of her natural capacities. On the material level France was not a grand pays, only a pays de bonheur whose retardation dated back to the 1920's when the Germans and Americans overwhelmed French industry. But by the time Hitler had annexed Austria in March 1938, Detoeuf began to fear (and with some justification) that Frenchmen hated one another more than they hated German hegemony in central Europe - and that they were refusing to choose between power and happiness. ${ }^{3} \mathrm{He}$ recommended termination of those eastern alliances which France was unwilling to honor, the revision of treaties according to Wilsonian principles: the important thing was to present Germany with a united France ready to defend its own frontiers.

The German march into the Sudetenland in the fall of 1938 held more moral and political lessons for France. Detoeuf did not join with those who protested the "humiliation" of France at Munich, since in his view France could not claim to make the rules of European politics. Yet he was concerned with the abandonment of the Czechs, because this act touched upon the credibility of the Third Republic

1 NC, No 14 (November 15, 1937), pp. 3-4.

2 Ibid., p. 4.

${ }^{3} \mathrm{NC}$, No 22 (April 1, 1938), pp. 1-3. 
and upon the conscience of the nation. The government, forced by public opinion to renew its guarantees to Czechoslovakia, had retreated at the last minute because, in Detoeuf's eyes, "The people would never have pardoned it had it staked the future, for an obscure motive, in an endless war." 1 These events demonstrated to Detoeuf the truth of an opinion he had held since the First World War: that government must partially insulate itself from the masses in order to develop a coherent program. In this crisis he suggested "unlimited powers for at least two years". ${ }^{2}$ On the other hand, he rejected a large armaments program out of vague fears of state bankruptcy and "totalitarianism". Once again he insisted that Germany could be held off not by victory in an arms race, but by national solidarity and moral rectitude. "The day France becomes anti-Semitic will be the day she abandons her soul", wrote Detoeuf in outrage after the Kristallnacht pogrom. ${ }^{3}$ As it was, France gave "the impression of having neither the sincerity of egoism nor the courage of friendship"; it seemed to be divided over every alternative policy. ${ }^{4}$ As a technicien Detoeuf believed that a clear statement of any problem would bring one halfway to the solution. But his objective seems, in retrospect, all too obvious: to stop Hitler without going to war with him. His search for certitudes and for points of national consensus dissolved into an inconclusive restatement of the confused views and policies which were making France vulnerable.

It was therefore with a sense of release that Detoeuf, like many others in the western democracies, identified Hitler's march into Prague in the spring of 1939 as the final, intolerable act of a barbarian who places himself outside the human community. ${ }^{\mathbf{5}}$ France had fortunately not confused the moral issue by going to war over the Sudetenland; Detoeuf was confident that the world would now stand with her against Hitler the outlaw and tyrant. And rather than taint France's position as defender of freedom, he rejected an alliance with the Soviet Union. At the outbreak of war in 1939, he set forth the ultimate aims which he believed worthy of the impending sacrifice of lives and personal liberty. ${ }^{6}$ Without being fully conscious of it, France was fighting not only for its own peace, but for the tranquility and unity of Europe. Economic and technical progress had outmoded the nation-state as an economic unit - now the war would destroy the

1 NC, No 33 (November 1, 1938), p. 2.

2 Ibid., p. 4.

${ }^{3} \mathrm{NC}$, No 35 (December 1, 1938), p. 2.

4 NC, No 38 (February 1, 1939), p. 1.

5 NC, No 42 (April 1, 1939), p. 1.

- NC, No 52 (December 1, 1939), pp. 18-21. 
idea of its usefulness as a political unit. The era of the nation had passed, and either a free Europe or a National Socialist Europe would emerge from the conflict. Detoeuf looked towards a post-war continental order based on a democratic constitution, a unified army, and a common market.

Nouveaux Cahiers ceased publication with the fall of France in 1940 , but Detoeuf continued to express his views privately. He found internal disunity a major cause of the defeat. The old cultural values, shared by all classes, had died with the best young men of his own generation on the battlefields of the First World War: "The strongest men were weary, weary, weary. The most cowardly had made, or were preparing to make, a fortune." In the post-war period even the veterans neglected the national interest as each scrambled to get his own share. Before 1914 everyone had been proud of his calling; success had corresponded with hard work, indolence with failure. Detoeuf, believer in the social benefits of progress in the twenties, now looked back nostalgically to France before 1914, when there were no vacations or automobile trips, but lovely Sundays in the country. He mocked one of Vichy's slogans: "France at work! We didn't talk about it when we were really working." 1

Nonetheless he was willing to lend his professional talents to this government led by Marshal Pétain which emerged from the defeat. He could not endorse its authoritarian and anti-Semitic policies; yet it offered Detoeuf (like many other frustrated reformers of the 1930's) a new opportunity to put his ideas into practice. Many of his colleagues from industry and the Nouveaux Cahiers also worked with the Vichy regime. Detoeuf shared, to a certain extent, the hopes of both the corporativist and the technocratic factions at Vichy - factions that competed for control of economic policy. His renewed affection for traditional France harmonized with his old scheme to re-establish industrial order and class collaboration; and he regarded his role in the government as an extension of his prewar activities. Detoeuf directed the Comité d'Organisation (CO) for electrical manufacturers, one of several such committees staffed by businessmen and supervised by the state which had been established for each branch of industry. ${ }^{2}$ The long-range purpose of the $\mathrm{CO}$ system was to modernize industrial

1 Quotations from letter to his brother (July 1941), in Pages retrouvées, pp. 68-72.

${ }^{2} \mathrm{He}$ demonstrated his ethical fastidiousness by resigning as manager at Thomson-Houston because he believed it might compromise his public responsibilities. Few other $\mathrm{CO}$ officials were so scrupulous (Jean-Guy Mérigot, Essai sur les Comités d'organisation professionnelle (1943), p. 303). For his experience with the $\mathrm{CO}$ see Detoeuf, Passé, présent, avenir de l'organisation professionnelle (1946), pp. 18-21. 
practice and to organize employers for membership in a planned economy; they made some headway against serious obstacles. Detoeuf also presided over a committee ${ }^{1}$ which drew-up a proposal to standardize and simplify the backward accounting methods used in industry, and to share production statistics with the state. He swallowed his aversion for state economic regulation, conceding its necessity at least in wartime, and attempted to persuade fellow businessmen that once the state was provided with accurate data, the worst abuses could be removed. But he complained that the CO's were confined to transmitting the government's orders.

He never, however, embraced the pure corporativism that dominated Pétain's circle. The corporativists proposed, among other things, grouping all those engaged in a "professional family" (such as the clothing industry) in common institutions armed with wide authority for self-government. Such corporativist bodies would end both the disorder of capitalism and the unnatural class struggle. Detoeuf openly dissented. ${ }^{2} \mathrm{He}$ repeated essentially what he had two years earlier told the critic of his Construction $d u$ syndicalisme: that a fundamental change in attitudes and values among both employers and employees would have to precede the creation of joint corporativist organs. Their mutual incomprehension and defensiveness would have to be broken down in the course of time, perhaps over several generations; Detoeuf wished merely to promote the dialogue between them in order to settle differences and to establish rules for cooperation. He left Vichy long before the regime lost its precarious autonomy vis-à-vis Germany and traded collaboration for genuine domestic reform. In spite of the opprobrium that surrounded Vichy at its collapse in 1944 many of its industrial reforms, championed by managers like Detoeuf, survived to influence post-war business practice. ${ }^{3}$

The liberation of France from German occupation in 1944-45 ended the Vichy experiment. It also brought Communist control of the CGT

1 The Commission du Plan Comptable (Detoeuf, Exposé sur le plan comptable, Centre d'Information Interprofessionnel, réunion du 30 juillet 1941 (n.d.)). Detoeuf also continued as president of CEGOS, which studied problems of labor relations and industrial statistics; the Vichy government regarded this commission seriously (Detoeuf et al., Les Techniques statistiques).

2 Detoeuf, "Réflexions sur le vieux corporatisme français", in: L'Organisation de la production industrielle [Collection Droit Social, XII] (1941), pp. 5-11. Corporativist doctrine is explained by Maurice Bouvier-Ajam, La Doctrine corporative, 4th ed. (1943); Matthew H. Elbow, French Corporative Theory, 1789-1948 (New York, 1953).

${ }^{3}$ Ehrmann, Business, pp. 58-100, et passim; Richard F. Kuisel, "Technocrats and Public Economic Policy: From the Third to the Fourth Republic", in: Journal of European Economic History, No 4 (1973), pp. 53-99. 
and the ostracism of the business community: under the leftist postwar government businessmen were commonly denounced as German collaborators, and it was a rare employer who broke silence in the prevailing hostile atmosphere. Detoeuf's friends noticed that he seemed disillusioned and frustrated: the gulf between management and labor had only widened and his hopes for class conciliation seemed more remote than ever. Nevertheless, even before the end of the war Detoeuf braved the tide of events and began writing a regular column on economic affairs for the bourgeois paper Le Figaro. The pressing problems of economic reconstruction stimulated once more the SaintSimonian impulse which had guided Detoeuf's early career. ${ }^{1}$ His themes were quite familiar: France could rebuild through hard work and sacrifice, through the creation of a spirit of loyal co-operation between labor and management, ${ }^{2}$ and through the adoption of American techniques to raise productivity and to initiate massive technological overhaul.

At a time when sweeping nationalization and outright confiscation threatened the private sector he assured his readers that a competitive market, a free labor force, and private initiative were essential to recovery. He deplored extreme measures of state control or socialism which, he believed, would end in state tyranny. Yet Detoeuf identified himself as one of industry's earliest and most enthusiastic advocates of economic planning. Even before Jean Monnet was officially charged by the government with preparing a plan, Detoeuf declared that during the existing period of acute penury, only the state could fairly determine priorities, allocate scarce materials, and in general guide reconstruction. He not only saw no incompatibility between a free economy and planning, but wrote, on the contrary, that "A solid plan is [...] the foundation of liberty" - that is, the surest way to protect the private sector from massive and erratic state interference. ${ }^{3}$ Modern private enterprise, too, required long-term planning and accurate market information. The only question, according to Detoeuf, was whether the directed economy would tend to maximize individual initiative, or would instead sacrifice freedom to convenience. Of the Monnet plan he wrote, in 1946: "France must still move mountains;

1 His views on post-war reconstruction appear in "Le Problème du travail français", in: Revue de Paris, September 1945, pp. 25-38; Le Figaro, especially April to November 1945.

2 He praised as "audacious but necessary" the government's creation of Comités d'Entreprise for all large plants - these committees were to promote industrial democracy and help overcome class antagonism by giving workers some share in managing company affairs (Le Figaro, May 15, 1945). On the committees' fate see Ehrmann, Business, pp. $446 \mathrm{ff}$.

${ }^{3}$ Le Figaro, October 25, 1945. 
it is faith in the future, symbolized by the plan, which will give the first push." 1 Although the Monnet plan was not perfect, Detoeuf celebrated it as a prodigious effort toward building solidarity.

Not only his endorsement of planning, but his acceptance of society's responsibility for the underprivileged marked Detoeuf's departure from economic liberalism. The Socialists and Communists could not guarantee employment merely by writing it into the constitution of the new republic, he pointed out. But he agreed with them that men who were victims of necessity did not enjoy true liberty, and that the security and dignity of the working class must be guaranteed. Therefore Detoeuf's column supported equality of opportunity - the democratization of education - while simultaneously attacking Socialist schemes for the confiscation of "nationalized" property in the name of equality of income. ${ }^{2}$

Writing for Le Figaro (as well as for other publications) and frequent speech-making kept the former manager active in the months following the war. He was then over sixty years old and in declining health, yet he had not lost his intellectual vigor. In a lecture at the Ecole Polytechnique he contrasted the students' probity and dedication to Cartesian principles with the profligacy of war profiteers, the "young captains of the black market". ${ }^{3}$ Other appeals he directed to the industrialists, to strengthen the employers' movement. ${ }^{4}$ His pre-war vision of France's role in world affairs had not altered: Gaullist calls to grandeur aroused his scorn. He called for internationalization of the Ruhr and the formation of a United Nations' police force. And his revival of faith in technocracy had not diminished his affection for the countryside. In February 1947, in what proved to be his final column before his death two months later, he urged the modernization of agriculture as a means of preserving as much as possible of the rural economy.

Even though Detoeuf had managed a dynamic corporation, he had equivocated on the question of industrial modernization. He suspected that his countrymen preferred the "happy mediocrity" of their traditional economy to an industrial society. As we have seen, he himself sometimes doubted that economic progress was worth the sacrifice of traditional ways and virtues, and he yearned to return to the simpler and happier Belle Epoque. During the depression these misgivings crowded out his optimism of the 1920's. Yet in his last years Detoeuf had returned to his earlier aspiration of making French capitalism

1 Ibid., December 7, 1946. Also ibid., January 28, 1947.

2 Ibid., June 4 and July 3, 1946.

${ }^{3}$ Lecture appeared ibid., February 1, 1946.

Detoeuf, Passé. 
more productive. While he clung to the liberal ideals of private initiative, competition, and the market economy, the true direction of his thought and action pointed toward technocracy. The mass of Frenchmen would benefit from the productive capacity of an organized industrial economy. Class conciliation built on negotiation and genuine respect between organized labor and management would supplant class warfare. Economic and social questions would be emptied of their political and ideological dimension. Privilege and the situations acquises would give way to meritocracy and a productivist work ethic.

In his quest for economic order, class conciliation, social justice, and European unity Detoeuf boldly broke with the official ideology and conventional practice of business under the Third Republic. $\mathrm{He}$ exposed French industrial retardation and the obsolescence of economic liberalism; he condemned such traditional business behavior as paternalism, individualism, protectionism, and economic nationalism. After the shock of the 1936 strikes and then the war, he participated with other reflective employers in the search for alternatives. While some looked forward to corporativism, Detoeuf championed double syndicalism, the patron social, industrial modernization, planning, and a European economy. His career stands at the historical juncture when French business underwent a serious self-examination; Detoeuf was its intellectual and moral conscience. 